\title{
ANALISIS IDENTIFIKASI SEKTOR PEREKONOMIAN SEBAGAI SEKTOR BASIS DAN SEKTOR POTENSIAL DI KOTA BOGOR
}

\author{
Resista Vikaliana \\ Institut Ilmu Sosial dan Manajemen STIAMI \\ email : resistav31@gmail.com
}

\begin{abstract}
Abstrak. Penelitian ini bertujuan untuk mengetahui sektor yang menjadi sektor basis dan non basis di Kota Bogor, lalu untuk mengetahui kinerja masing-masing sektor di Kota Bogor, serta untuk mengetahui sektor yang menjadi sektor potensial di Kota Bogor. Penelitian dilakukan dengan menggunakan metode Location Quotient/ LQ. Di Kota Bogor, dari kurun waktu 2011 hingga 2015 terdapat satu sektor basis tertinggi yakni sektor pengadaan listrik dan gas. Dari 16 sektor ekonomi, sektor ekonomi yang termasuk sektor basis pada 2011adalah pengadaaan listrik dan gas, sektor transportasi dan pergudangan, sektor jasa keuangan dan asuransi serta sektor jasa lainnya. Selain keempat sektor pada tahun 2011, pada tahun 2012-2015, bertambah 7 sektor, menjadi 11. Tambahan sektor itu adalah sektor basis.sektor pengadaan air, pengelolaan sampah, limbah, sektor konstruksi, serta sektor perdagangan besar dan eceran; reparasi mobil dan sepeda motor, sektor penyediaan akomodasi, makanan dan minuman, sektor informasi dan komunikasi, sektor jasa perusahaan, sektor jasa kesehatan dan kegiatan sosial. kemudian yang termasuk dalam sektor non basis adalah lima sektor lainnya.

Di Kota Bogor kinerja sektor perekonomiannya dapat dijelaskan bahwa sektor yang memiliki nilai rata-rata Pertumbuhan Regional (PR) tertinggi yakni sektor pengadaan listrik dan gas . Nilai ini mengindikasikan bahwa pertumbuhan dari sektor pengadaan listrik dan gas di Kota Bogor lebih tinggi dibandingkan dengan Indonesia. Di Kota Bogor dari tahun 2011 hingga 2015 yang termasuk dalam sektor potensial adalah sektor . Kemudian dari sektor-sektor tersebut, sektor yang paling potensial atau dapat dikatakan sebagai sektor paling potensial adalah sektor pengadaan listrik dan gas.

Dari hasil penelitian yang telah diperoleh oleh peneliti, maka peneliti memberikan saran yang harus diambil adalah sebagai berikut : Pertama, sektor basis hendaknya harus lebih dijaga dan dikembangkan lagi tanpa menyampingkan pembangunan terhadap sektor-sektor yang lain. Sektor pengadaan listrik dan gas yang memberikan kontribusi terhadap PDRB hendaknya dikembangkan dengan cara melakukan industrialisasi bekerja sama dengan investor, sehingga kontribusi dari sektor pengadaan gas dan listrik dapat kembali meningkat. Kedua, perencanaan dalam pembangunan hendaknya diberikan terhadap sektor-sektor yang memiliki potensi untuk dikembangkan sebagai prioritas utama sehingga pembangunan yang dilakukan nantinya dapat dilaksanakan dengan lebih optimal.
\end{abstract}

Kata kunci : Sektor ekonomi basis, sektor non basis, Location Quotient/ LQ Method

Abstract. This study aims to determine the sectors that become the basis sector and non-base in the city of Bogor, then to know the performance of each sector in the city of Bogor, and to know the sector that became a potential sector in the city of Bogor. The research was conducted by using Location Quotient / LQ method. In the city of Bogor, from the period of 2011 to 2015 there is one sector of the highest base of electricity and gas procurement sector. Of the 16 economic sectors, the economic sector including the basic sector in 2011 is the procurement of 
electricity and gas, the transportation and warehousing sectors, the financial services sector and insurance and other services sectors. In addition to these four sectors in 2011, in 20122015, it increased by 7 sectors, to 11. The additional sectors were water supply, waste management, waste, construction, and large and retail trade sectors; car and motorcycle repair, accommodation, food and beverage sector, information and communications sector, corporate services sector, health services sector and social activities. then that included in the non-base sector is the other five sectors.

In the city of Bogor the performance of the economic sector can be explained that the sector that has the average value of Regional Growth $(P R)$ is the highest sector of procurement of electricity and gas. This value indicates that the growth of electricity and gas procurement sector in Bogor City is higher than that of Indonesia. In Bogor City from 2011 to 2015 included in the potential sector is sector. Then from these sectors, the most potential sector or the most potential sector is the electricity and gas procurement sector.

From the results of research that has been obtained by researchers, the researchers provide suggestions that must be taken are as follows: First, the base sector should be more maintained and developed again without exclude development against other sectors. The electricity and gas procurement sector that contributes to the GRDP should be developed by industrializing in cooperation with investors, so that the contribution from the gas and electricity procurement sector can increase again. Second, planning in development should be given to sectors that have the potential to be developed as a top priority so that development can be carried out more

optimally.

Keywords: Economic sector base, non-base sector, Location Quotient / LQ Method

\section{PENDAHULUAN}

Dalam mencapai kesejahteraan masyarakat dan taraf hidup di masingmasing daerah, dibutuhkan pembangunan ekonomi berkesinambungan. Proses untuk meraihnya, tidak lepas dari permasalahan. Masalah yang sering terjadi dalam pembangunan ekonomi daerah terletak pada kebijakan-kebijakan yang ditetapkan oleh pemerintah daerah, yang seringkali tidak sesuai dengan potensi-potensi yang dimiliki oleh daerah yang bersangkutan untuk menggunakan sumberdaya yang ada. Padahal, setiap daerah memiliki karakteristik tersendiri sehingga memiliki potensi yang berbeda-beda dengan daerah lain. Untuk dapat mengetahui perkembangan perekonomian suatu daerah dapat dilihat melalui data dari pendapatan regional daerah tersebut atau yang disebut Pendapatan
Domestik Regional Bruto/ PDRB. PDRB di Indonesia pada dasarnya terdiri atas 16 sektor (BPS Kota Bogor,:2016), yaitu

1. Sektor pertanian; kehutanan, perikanan

2. Sektor pertambangan dan penggalian

3. Sektor industri pengolahan

4. Sektor listrik dan gas

5. Sektor air bersih; pengelolaan sampah, limbah

6. Sektor konstruksi

7. Sektor perdagangan besar dan eceran, reparasi mobil dan sepeda motor

8. Sektor transportasi dan pergudangan

9. Sektor penyediaan akomodasi dan makan minum

10. Sektor informasi dan komunikasi

11. Sektor jasa keuangan dan asuransi

12. Sektor real estate

13. Sektor jasa perusahaan 
Resista Vikaliana, Analisis Identifikasi Sektor Perekonomian Sebagai Sektor Basis ...

14. Sektor administrasi pemerintahan, pertahanan dan jaminan sosial wajib

15. Sektor jasa pendidikan

16. Sektor jasa kesehatan dan kegiatan sosial

17. Sektor jasa lainnya

Kontribusi terbesar Pendapatan Asli Daerah (PAD) Kota Bogor tahun 2016, disumbangkan oleh jenis pajak di sektor kepariwisataan dan jasa. Ketiganya adalah berasal dari pajak restoran, pajak hotel, dan pajak hiburan. Tingginya pendapatan dari ketiga jenis pajak itu, menurut Walikota Bogor, besar kemungkinan lantaran dampak dari penggunaan tapping box yang dipasang yang telah dilakukan Pemerintah Kota Bogor melalui Badan Pendapatan Daerah di hotel-hotel dan restoran. (www. jabarprov.go.id, 2017). Sektor pariwisata menjadi penyumbang PAD terbesar bagi Kota Bogor. Hal ini diperkuat oleh pendapat Kepala Dinas Kebudayaan, Pariwisata dan Ekonomi Kreatif, peningkatan PAD di sektor pariwisata terutama dari usaha kuliner. Sumbangan sektor kuliner bagi pendapatan asli daerah naik hingga sebesar 31 persen pada 2016.

Sektor Perdagangan Besar dan Eceran, Reparasi Mobil dan Sepeda Motor merupakan sektor dengan PDRB terbesar Kota Bogor. SelanjutnyA, penyumbang PDRB terbesar kedua adalah sektor industri pengolahan, sedangkan penyumbang PDRB terbesar ketiga ditempati oleh sektor transportasi dan pergudangan. Dari data tersebut, yang memiliki peranan penting dalam perekonomian Kota Bogor terletak pada sektor perdagangan besar dan eceran, reparasi mobil dan sepeda motor. Namun dilihat lebih lanjut lagi, pertumbuhan sektor ini mengalami penurunan persentase dalam memberikan sumbangan terhadap total PDRB Kota Bogor. Dengan kata lain dapat dikatakan bahwa perkembangan sektor perdagangan besar dan eceran, reparasi mobil dan sepeda motor mengalami penurunan jika dibandingkan dengan sektor- sektor lainnya. Oleh karena itu Pemerintah Kota Bogor harus mengetahui dengan pasti hal-hal apa saja yang dapat menjadi kekuatan atau kelemahan dari daerahnya, sehingga pemerintah daerah dapat meningkatkan daya saing daerahnya.

Salah satu sasaran pembangunan ekonomi wilayah jangka panjang adalah terjadinya pergeseran pada struktur ekonomi wilayah yang terjadi akibat kemajuan pembangunan suatu wilayah. Tidak semua sektor dalam perekonomian memiliki kemampuan tumbuh yang sama, maka perencana pembangunan wilayah biasanya akan memanfaatkan sektor-sektor basis yang dianggap dapat mendorong pertumbuhan ekonomi. (Daryanto dkk, 2010). Pengembangan potensi yang dimiliki suatu daerah secara maksimal akan mendatangkan suatu keuntungan bagi daerahnya tersebut. Dengan memaksimalkan kegiatan ekonomi pada sektor potensial, nantinya sektor tersebut akan berkembang dan dapat menjadi sektor basis pada daerah tersebut. Peningkatan kegiatan ekonomi di sektor basis maupun sektor potensial daerah akan berimbas pada peningkatan PDRB daerah tersebut. Hal ini disebabkan dengan adanya spesialisasi sesuai dengan sektor atau sub sektor unggulan yang dimiliki masingmasing daerah nantinya akan dapat digunakan untuk meningkatkan efektifitas dan efisiensi masyarakat dalam melaksanakan kegiatan ekonomi. Sehingga, pemerintah daerah harus mengetahui dengan pasti apa saja yang merupakan sektor basis maupun sektor non basis serta sektor-sektor mana sajakah yang memiliki potensi untuk dikembangkan sehingga nantinya sektor potensial tersebut dapat menjadi sektor basis yang baru di daerah tersebut.

Dari uraian yang telah disampaikan di atas, penulis tertarik untuk mengetahui sektor-sektor mana sajakah di Kota Bogor yang merupakan sektor basis dan non basis serta sektor mana sajakah yang merupakan 
sektor yang memiliki potensi yang dapat dikembangkan untuk meningkatkan pembangunan daerah. Berdasarkan latar belakang tersebut, rumusan masalahnya adalah 1. Sektor apa sajakah yang menjadi sektor basis dan non basis di Kota Bogor? 2. Bagaimanakah kinerja masing-masing sektor di Kota Bogor? 3. Sektor apakah yang menjadi sektor potensial di Kota Bogor?.

Dari rumusan masalah yang telah dipaparkan dapat ditarik tujuan dari penelitian ini adalah; 1. Untuk mengetahu sektor yang menjadi sektor basis dan non basis di Kota Bogor, 2. Untuk mengetahui kinerja masing-masing sektor di Kota Bogor, 3. Untuk mengetahui sektor yang menjadi sektor potensial di Kota Bogor.

\section{TELAAH PUSTAKA}

\section{Pembangunan Ekonomi}

Pembangunan ekonomi merupakan salah satu jawaban yang seakan-akan menjadi semacam kunci keberhasilan bagi suatu negara untuk meningkatkan taraf hidup warga negaranya. Ilmu ekonomi pembangunan lebih mengacu pada masalahmasalah perkembangan ekonomi di negaranegara terbelakang. Istilah perkembangan ekonomi itu sendiri digunakan secara bergantian dengan istilah seperti pertumbuhan ekonomi. Akan tetapi beberapa ahli ekonom tertentu menarik perbedaan yang lazim antara istilahperkembangan ekonomi dan pertumbuhan ekonomi. Menurut Schumpeter perkembangan ekonomi adalah perubahan spontan dan terputus-putus dalam keadaan stasioner yang senantiasa mengubah dan mengganti situasikeseimbangan yang ada sebelumnya, sedangkan pertumbuhan ekonomi adalah perubahan jangka panjang secara perlahan dan mantap yang terjadi melalui kenaikan tabungan dan penduduk.
Pembahasan ekonomi pembangunan pada dasarnya tidak lepas dari kaidah-kaidah ekonomi baik secara mikro maupun makro.Pembahasan ilmu ekonomi selalu berkaitan terutama dengan efisiensi dan alokasi sumber-sumber produktif yang langka, dan dengan pertumbuhan yang optimaldari sumber-sumber itu untuk menghasilkan barang-barang dan jasa-jasa yang lebih besar.Sedangkan ekonomi pembangunan memiliki ruang lingkup yang lebih luas dan kompleks. Pembangunan ekonomi itu sendiri menurut Mudrajad (2004) adalah proses penciptaan suatu lingkungan oleh masyarakat yang mempengaruhi hasil-hasil indikator ekonomi seperti kenaikan kesempatan kerja dan pertumbuhan ekonomi.

\section{Teori Basis Ekonomi}

Teori basis ekonomi mendasarkan pandangannya bahwa laju pertumbuhan ekonomi suatu wilayah ditentukan oleh besarnya peningkatan ekspor dari wilayah tersebut.Kegiatan ekonomi dikelompokkan atas kegiatan basis dan kegiatan non basis. Kegiatan basis adalah kegiatan yang bersifat eksogen artinya tidak terikat pada kondisi internal perekonomian wilayah dan sekaligus berfungsi sebagai pendorong tumbuhnya jenis pekerjaan lain, sedangkan pekerjaan non basis adalah kegiatan yang bersifat endogen (tidak tumbuh bebas) artinya kegiatan untuk memenuhi kebutuhan masyarakat didaerah itu sendiri dan pertumbuhannya tergantung pada kondisi umum perekonomian wilayah tersebut (Tarigan, 2005).

Terdapat beberapa cara yang dapat digunakan dalam memilah antara kegiatan basis dan kegiatan non basis. (1) Metode langsung dapat dilakukan dengan cara survei secara langsung kepada pelaku usaha kemana mereka memasarkan barang yang 
Resista Vikaliana, Analisis Identifikasi Sektor Perekonomian Sebagai Sektor Basis ...

diproduksi dan dari mana mereka membeli bahan-bahan kebutuhan untuk menghasilkan produk tersebut. (2) metode tidak langsung adalah dengan menggunakan asumsi atau disebut dengan metode asumsi. Dalam metode asumsi, berdasarkan kondisi diwilayah tersebut (berdasarkan data sekunder), ada kegiatan tertentu yang diasumsikan sebagai kegiatan basis dan kegiatan lainnya sebagai kegiatan non basis. (3) Yang sering dilakukan orang adalah gabungan antara metode asumsi dengan metode langsung yang disebut metode campuran. (4) Metode Location Quotient (LQ) membandingkan porsi lapangan kerja/nilai tambah untuk sektor tertentu di wilayah yang dibandingkan dengan porsi lapangan kerja/nilai tambah untuk sektor yang sama secara nasional.

\section{Teori Pembangunan Ekonomi Wilayah}

Adisasmita (2005) menjelaskan bahwa pembangunan ekonomi wilayah (regional) merupakan fungsi dari potensi sumber daya alam, tenaga kerja dan sumber daya manusia, investasi modal, sarana dan prasarana pembangunan, transportasi dan komunikasi, komposisi industri, teknologi, situasi ekonomi, dan perdagangan antar wilayah, kemampuan pendanaan dan pembiayaan pembangunan daerah, kewirausahaan, kelembagaan daerah dan lingkungan pembangunan secara luas.

Dalam teori pembangunan ekonomi wilayah ini terdapat teori yang terkenal yang dikemukakan oleh Richardson.Dalam teorinya Richardson membagi kegiatan produksi/jenis pekerjaan yang terdapat di dalam satu wilayah atas pekerjaan basis (dasar) dan pekerjaan service (pelayanan), untuk menghindari kesalahpahaman disebut saja sektor nonbasis.Kegiatan basis adalah kegiatan yang bersifat exogenous artinya tidak terikat pada kondisi internal perekonomian wilayah dan sekaligus berfungsi mendorong tumbuhnya jenis pekerjaan lainnya. Sedangkan pekerjaan service (nonbasis) adalah kegiatan untuk memenuhi kebutuhan masyarakat didaerah itu sendiri. Oleh karena itu pertumbuhannya

Melalui perencanaan pembangunan ekonomi daerah, suatu daerah dilihat secara keseluruhan sebagai suatu unit ekonomi (economic entity) yang di dalamnya terdapat berbagai unsur yang berinteraksi satu sama lain. Setidaknya terdapat tiga unsur dasar dari perencanaan pembangunan ekonomi daerah jika dikaitkan dengan hubungan pusat dan daerah (Mudrajad, 2004) : (1) Perencanaan pembangunan daerah yang realistic memerlukan pemahaman tentang hubungan antara daerah dengan lingkungan nasional ditempat daerah tersebut merupakan bagian darinya, keterkaitan secara mendasar antara keduanya, dan konsekuensi akhir dari interaksi tersebut. (2) Sesuatu yang tampaknya baik secara nasional belum tentu baik untuk daerah, dan sebaliknya yang baik menurut daerah belum tentu baik secara nasional. (3) Perangkat kelembagaan yang tersedia untuk pembangunan daerah, misalnya administrasi, proses pengambilan keputusan, dan otoritas biasanya sangat berbeda untuk tingkat daerah dengan yang tersedia pada tingkat pusat. Selain itu, derajat pengendalian kebijakan sangat berbeda pada dua tingkat tersebut. Oleh karena itu, perencanaan daerah yang efektif harus bisa membedakan apa yang seyogyanya dilakukan dan apa yang dapat dilakukan, dengan menggunakan bernagai sumber daya pembangunan sebaik mungkin sehingga benar-benar dapat dicapai, dan mengambil manfaat dari informasi yang lengkap dan tersedia pada tingkat daerah karena kedekatan para perencananya dengan objek perencanaan.

\section{Penelitian Terdahulu}

Mushoffa (2009) meneliti Analisis Sektor Basis dan Strategi Pengembangan 
Potensi Ekonomi Daerah di Kabupaten Tegal. Permasalahan yang dikaji dalam penelitian ini adalah: (1) Sektor -sektor ekonomi manakah yang termasuk sektor basis tiap kecamatan yang dapat dikembangkan lebih lanjut di Kabupaten Tegal?, (2) Strategi apakah yang harus diterapkan dalam pengembangan potensi ekonomi daerah di Kabupaten Tegal? Penelitian ini bertujuan: (1) Menganalisis sektor ekonomi mana saja yang termasuk sektor basis tiap kecamatan yang dapat dikembangkan lebih lanjut di Kabupaten Tegal, (2) Menganalisis dan mengetahui strategi yang harus diterapkan dalam pengembangan potensi ekonomi daerah di Kabupaten Tegal. Penelitian ini menggunakan data sekunder dan data primer. Data sekunder bersumber dari BPS (Badan Pusat Statistik), sedangkan data primer bersumber dari pegawai dinas pertanian, dinas industri dan perdagangan Kabupaten Tegal, Cara memperoleh data dengan metode dokumentasi dan kuesioner. Data diolah dengan teknik analisis Location Question dan analisis SWOT (Strenghts, Weaknesses, Oppurtunities, Threats).

Berdasarkan hasil penelitian dan pembahasan dapat disimpulkan sebagai berikut. Pertama, sektor basis tiap kecamatan di Kabupaten Tegal.

Kedua, strategi yang harus diterapkan dalam pengembangan potensi ekonomi daerah di Kabupaten Tegal sebagai berikut. (1) Sektor pertanian: Pembuatan teknologi tepat guna dengan menerapkan teknologi ramah lingkungan, menciptakan jaringan ekonomi ditingkat pedesaan guna memanfaatkan potensi sumber daya pertanian, pegembangan sarana dan prasarana pertanian, pengembangan SDM petani melalui program penyuluhan pertanian, menciptakan usaha pertanian yang berorientasi pada agribisnis, pengembangan teknologi pengendalian hama terpadu, pengembangan program bantuan bagi lembaga usaha ekonomi pedesaan (LUEP) dan peningkatan pemanfaatan teknologi serta mutu hasil pertanian. (2) Sektor industri: peningkatan pengembangan zona atau wilayah industri beserta sarana dan prasarananya, peningkatan sumber daya manusia dan penyediaan modal kerja untuk mengembangkan potensi sektor industri, pelatihan peningkatan kualitas produksi dan perkuatan struktur modal, peningkatan segmen pasar dan bantuan pinjaman modal untuk sarana produksi, pengendalian pencemaran lingkungan dengan cara meminimalisir produksi limbah yang dihasilkan selama proses produksi, meningkatkan peluang pasar produk industri terutama industri kecil dengan sistem inovasi berteknologi industri, meningkatkan kualitas dan kompetensi pengusaha dalam rangka peningkatan daya saing produk industri, mengembangkan usaha industri yang memanfaatkan sumber daya secara efektif dan efisien. (3) Sektor perdagangan: peningkatan sarana prasarana, kualitas produk dan pemasaran, peningkatan kemampuan pengusaha kecil dan menengah, pelatihan manajemen bagi pengusaha kecil dan menengah (PKM), pemberian bantuan pinjaman modal bagi pengusaha kecil dan menengah, meningkatkan kegiatan pengawasan barang dan jasa yang beredar di pasar, mengadakan kegiatan pasar murah di wilayah kecamatan, melaksanakan sosialisasi peijinan di bidang perdagangan, penerapan teknologi tepat guna di bidang perdagangan, peningkatan SDM dan kualitas di bidang perdagangan, pengembangan perdagangan dan sistem distribusi. 
Resista Vikaliana, Analisis Identifikasi Sektor Perekonomian Sebagai Sektor Basis ...

Saran yang diajukan, pengembangan potensi ekonomi daerah yang dilakukan oleh pemerintah Kabupaten Tegal hendaknya tidak hanya ditekankan pada pengembangan sektor pertanian, industri, dan perdagangan saja, akan tetapi juga memperhatikan pengembangan sektor-sektor basis yang dimiliki oleh kecamatan. Sehingga kecamatan -kecamatan yang mempunyai nilai tambah kecil dari sektor pertanian, industri, dan perdagangan dapat didukung dari sektor lainnya yang merupakan sektor basis.

Penelitian lain dilakukan oleh Yuuhaa dkk (2011) Penelitian yang dilakukan di Kabupaten Lamongan ini memiliki tujuan untuk mengetahui dan menganalisis sektor basis dan non basis yang ada, kinerja dari sektor perekonomian dan juga untuk mengetahui sektor potensial yang ada di Kabupaten Lamongan. Dalam penelitian ini menggunakan jenis penelitian deskriptif kuantitatif dengan model perencaanaan pembangunan. Data yang digunakan merupakan data time series yakni data PDRB Kabupaten Lamongan tahun 2007 sampai 2011 yang akan dianalisis dengan menggunakan tiga alat analisis yaitu Location Quotient (LQ), Shift Share (SS) dan Model Rasio Pertumbuhan (MRP).

Hasil analisis LQ menunjukkan bahwa yang termasuk sektor basis adalah sektor pertanian. Kemudian dari analisis Shift Share menunjukkan kinerja dari masing-masing sektor di Kabupaten Lamongan dimana sektor pertanian memiliki pertumbuhan tertinggi dibandingkan pertumbuhan Jawa Timur, sektor perdagangan, hotel dan restoran dapat dikatakan sektor yang paling maju dan memiliki daya saing yang tinggi di Kabupaten Lamongan. Selanjutnya dari hasil analisis MRP menunjukkan bahwa sektor yang termasuk dalam sektor potensial di Kabupaten Lamongan adalah sektor pertanian, sektor industri pengolahan, sektor listrik, gas dan air bersih dan sektor jasajasa.

\section{METODE PENELITIAN}

Jenis penelitian ini adalah jenis penelitian deskriptif dengan pendekatan kuantitatif dengan model perencanaan pembangunan. Data yang digunakan merupakan data sekunder yang didapat dari BPS Kota Bogor dan BPS (nasional) tahun 2011-2015. Untuk melengkapi data yang dibutuhkan oleh penulis, maka data dikumpulkan dan diolah dengan metode analisis data untuk menjawab rumusan masalah. Adapun teknik analisis data yang digunakan adalah Analisis Location Quotient (LQ)

Analisis LQ digunakan untuk menentukan sektor basis dan non basis melalui pendekatan nilai tambah PDRB dan pendekatan jumlah tenaga kerja masingmasing sektor. Dalam penelitian ini peneliti menggunakan pendekatan nilai tambah PDRB dimana rumus yang digunakan adalah sebagai berikut :

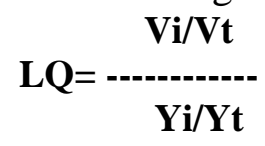

Ket:

$$
\begin{aligned}
& \mathrm{Vi}=\text { Nilai PDRB pada Sector I } \\
& \text { pada tingkat wilayah yang lebih } \\
& \text { rendah (studi) } \\
& \mathrm{Vt}=\text { Total PDRB pada tigkat } \\
& \text { wilayah Yang lebih rendah } \\
& \text { (studi) } \\
& \mathrm{Yi}=\text { Nilai PDRB pada Sector I } \\
& \text { pada tingkat wilayah yang lebih } \\
& \text { tinggi (referensi) } \\
& \text { Yt = Total PDRB pada tingkat } \\
& \text { wilayah yang lebih tinggi }
\end{aligned}
$$


Jurnal Ilmiah Ilmu Administrasi

ISSN 2085-1162

\section{(referensi)}

Dengan ketentuan bahwa apabila nilai LQ > 1 maka sektor tersebut merupakan sektor basis yang menjadi kekuatan daerah untuk mengekspor produknya keluar daerah bersangkutan. Sebaliknya jika $\mathrm{LQ}<1$ maka sektor tersebut menjadi pengimpor atau sektor non basis. Dan jika LQ = 1 maka ada kecenderungan sektor tersebut bersifat tertutup karena tidak melakukan transaksi ke dan dari luar wilayah, namun kondisi seperti ini jarang ditemukan dalam sebuah perekonomian wilayah.

\section{HASIL DAN PEMBAHASAN}

\section{Analisis LQ}

Analisis Location Quotient ini digunakan untuk mengetahui manakah yang termasuk sektor basis dan non basis di Kota Bogor dari 16 sektor ekonomi yang ada.Dalam analisis LQ ini ditentukan kriteria dimana jika suatu sektor memiliki nilai $L Q>1$ maka sektor tersebut termasuk sektor basis dan jika nilai $\mathrm{LQ}<1$ maka sektor tersebut termasuk sektor non basis.Berikut ini adalah hasil perhitungan dari analisis Location Quotient (LQ) di Kota Bogor dari tahun 2011-2015.

\section{Tabel 1 Distribusi Persentase PDRB Seri 2010 \\ Menurut Lapangan Usaha di Kota Bogor Tahun 2011-2015 (Persen)}

\begin{tabular}{|c|c|c|c|c|c|c|}
\hline Kategori & Uraian & 2011 & 2012 & 2013 & 2014 & 2015 \\
\hline (1) & (2) & (3) & (4) & (5) & (6) & (7) \\
\hline A & Pertanian, Kehutanan, dan Perikanan & 1,02 & 0,95 & 0,89 & 0,83 & 0,78 \\
\hline B & Pertambangan dan Penggalian & 0,00 & 0,00 & 0,00 & 0,00 & 0,00 \\
\hline C & Industri Pengolahan & 19,95 & 19,23 & 18,55 & 18,50 & 18,54 \\
\hline D & Pengadaan Listrik dan Gas & 4,87 & 5,45 & 5,81 & 6,73 & 5,95 \\
\hline E & Pengadaan Air, Pengelolaan Sampah, Limbah & 0,10 & 0,11 & 0,11 & 0,10 & 0,10 \\
\hline $\mathrm{F}$ & Konstruksi & 11,19 & 11,27 & 11,37 & 11,25 & 11,27 \\
\hline G & $\begin{array}{l}\text { Perdagangan Besar dan Eceran; Reparasi Mobil } \\
\text { dan Sepeda Motor }\end{array}$ & 22,73 & 22,75 & 22,73 & 22,22 & 21,91 \\
\hline H & Transportasi dan Pergudangan & 10,80 & 10,96 & 11,10 & 10,81 & 11,67 \\
\hline $\mathbf{I}$ & Penyediaan Akomodasi dan Makan Minum & 4,39 & 4,36 & 4,49 & 4,44 & 4,39 \\
\hline J & Informasi dan Komunikasi & 4,30 & 4,31 & 4,16 & 4,41 & 4,70 \\
\hline K & Jasa Keuangan dan Asuransi & 6,59 & 6,55 & 6,92 & 6,78 & 6,61 \\
\hline L & Real Estate & 2,16 & 2,20 & 2,22 & 2,24 & 2,21 \\
\hline $\mathrm{M}, \mathrm{N}$ & Jasa Perusahaan & 2,01 & 2,03 & 2,04 & 2,04 & 2,09 \\
\hline 0 & $\begin{array}{l}\text { Administrasi Pemerintahan, Pertahanan dan } \\
\text { Jaminan Sosial Waiib }\end{array}$ & 3,18 & 3,21 & 3,02 & 3,02 & 2,95 \\
\hline $\mathbf{P}$ & Jasa Pendidikan & 2,33 & 2,48 & 2,63 & 2,74 & 2,80 \\
\hline Q & Jasa Kesehatan dan Kegiatan Sosial & 1,09 & 1,06 & 1,03 & 1,09 & 1,16 \\
\hline$R, S, T, U$ & Jasa lainnya & 3,30 & 3,10 & 2,94 & 2,80 & 2,86 \\
\hline & PRODUK DOMESTIK REGIONAL BRUTO & 100,00 & 100,00 & 100,00 & 100,00 & 100,00 \\
\hline PRODUV & IK DOMESTIK REGIONAL BRUTO TANPA MIGAS & 100,00 & 100,00 & 100,00 & 100,00 & 100,00 \\
\hline
\end{tabular}

Sumber : BPS Kota Bogor, 2016 
Resista Vikaliana, Analisis Identifikasi Sektor Perekonomian Sebagai Sektor Basis ...

Tabel 2 Hasil Pengolahan Data dengan Metode LQ

\begin{tabular}{|c|c|c|c|c|c|c|c|c|c|c|c|c|c|c|c|c|}
\hline \multirow{2}{*}{ Kalegonil } & \multirow{2}{*}{ Uraian } & \multicolumn{3}{|c|}{2011} & \multicolumn{3}{|c|}{2012} & \multicolumn{3}{|c|}{2013} & \multicolumn{3}{|c|}{2014} & \multicolumn{3}{|c|}{2015} \\
\hline & & Kota Bogol & Indonesia & LQ & Kota Bogor: & Indonesia & LQ & Kota Bogot & Indonesia & LQ & Kota Bogot & Indonesia & LQ & Kota Bogoor & Indonesia & LQ \\
\hline A & Pertanian, Kehutanand dan Perilkanan & 1.02 & $1,058,245,30$ & 0.04 & 0.95 & $1,1,152,262,10$ & 0.07 & 0.89 & $1,275,048.40$ & 0.07 & 0.83 & $1,409,655,70$ & 0.06 & 0.78 & $1,560,399,30$ & 0.06 \\
\hline$B$ & Pertambangean dan Pengogalian & . & 924813.4 & . & . & $1,000,307,60$ & . & . & $1,050,745.80$ & . & . & $1,042,900,90$ & . & . & $879,399,60$ & . \\
\hline $\bar{C}$ & Industri Pengolahan & 19.95 & $1,204,250,50$ & 0.70 & 19.23 & $1,848,150,90$ & 0.90 & $8.5 j$ & $2,007,462,80$ & 0.44 & 18.50 & $2,19,441.40$ & 0.86 & 18.54 & $2,405,408,90$ & 0.86 \\
\hline D & Pengadann Listrilid dan Gas & 4.87 & $91,721.90$ & 2.23 & 5.45 & $95,637.80$ & 4.91 & 5.81 & $98,686.80$ & 6.09 & 6.73 & $114,617,90$ & 6.05 & 505 & $131,264.20$ & 5.07 \\
\hline E & $\begin{array}{l}\text { Pengadoan Air, Pengelolazan Sampah, } \\
\text { Limbah }\end{array}$ & 0.10 & $6,208.80$ & 0.68 & 0.11 & $6,6038.80$ & 1.44 & 0.11 & $7,209,00$ & 1.58 & 0.10 & $7,887.10$ & 1.31 & 0.10 & $8,606.00$ & 1.30 \\
\hline P & Konstrutkis & 111.19 & $712,184,40$ & 0.66 & 11.27 & $805,208.10$ & 1.21 & 11.37 & $905,990.50$ & 1.30 & 11.25 & $1,041,949,50$ & 1.11 & 11.27 & $1,193,346.10$ & 1.06 \\
\hline G & $\begin{array}{l}\text { Perdaganngan Besar dan Eceran, } \\
\text { Reparasi:Mobil dan Sepecda.Motor }\end{array}$ & 22.73 & $1,066,092.10$ & 0.89 & 22.75 & $1,1,38,484,40$ & 1.72 & 22.73 & $1,261,145,60$ & 1.86 & 22.22 & $1,420,054,30$ & 1.61 & 21.91 & $1,534,067,30$ & 1.60 \\
\hline $\mathrm{H}$ & Transpootasi dan Pergudangan & 10.80 & $276,122,40$ & 1.64 & 10.96 & $313,156,20$ & 3.02 & 11.10 & $375,305.90$ & 3.06 & 10.81 & $466,968,90$ & 238 & 11.67 & $578,963.90$ & 2.25 \\
\hline I & $\begin{array}{l}\text { Penvedizan Aloomodas idan Makan } \\
\text { Minum }\end{array}$ & 4.39 & $224,215.30$ & 0.82 & 4.36 & $252,612,2.30$ & 1.49 & 4.49 & $289,498,30$ & 1.60 & 4.44 & $321,062.10$ & 1.42 & 4.39 & $341,790.20$ & 1.44 \\
\hline J & Informasi dan Komunilass' & 4.30 & $281,777.60$ & 0.64 & 4.31 & $311,362,40$ & 1.19 & 4.16 & $341,009,40$ & 1.26 & 4.4! & $369,415.00$ & 1.23 & 4.70 & $406,887,60$ & 1.29 \\
\hline $\bar{K}$ & Jasa Kevangean dan Asuransi & 6.59 & $270,586.30$ & 1.02 & $6.5 j$ & $320,534,30$ & 1.76 & 6.92 & $370,131.90$ & 1.93 & 6.78 & $408,439.80$ & 1.71 & 6.61 & $464,734,60$ & 1.59 \\
\hline L & Real Estate & 2.16 & $218,796,60$ & 0.41 & 2.20 & 237,913:90 & 0.80 & 2.22 & $264,275.00$ & 0.87 & 2.24 & $294,573,40$ & 0.78 & 2.21 & $329,796,90$ & 0.75 \\
\hline \begin{tabular}{l|l} 
MNI \\
\end{tabular} & Jasa Perusahazan & 201 & $113,975.30$ & 0.74 & 203 & $127,724.20$ & 1.37 & 2.04 & $144,604.10$ & 1.46 & 2.04 & $165,990.60$ & 1.27 & 200 & $190,267,90$ & 1.23 \\
\hline 0 & $\begin{array}{l}\text { Administrasis Pemerintahan, } \\
\text { Pertahanant dan Jaminan Sosial Wailo }\end{array}$ & 3.18 & $304,755,70$ & 0.44 & 3.21 & $340,567,60$ & 0.81 & 3.02 & $372,195.00$ & 0.84 & 3.02 & $404,629.60$ & 0.77 & 2.95 & $450,733.10$ & 0.73 \\
\hline P & Jass Pendidilizan & 233 & $232,726,80$ & 0.42 & 2.48 & $270,372,30$ & 0.79 & 2.63 & $307,862.30$ & 0.88 & 2.74 & 342,06320 & 0.83 & 280 & $388,602,60$ & 0.81 \\
\hline Q & Jassa Keselatian dan Kegiatian Sosial & 1.09 & $76,404.90$ & 0.60 & 1.06 & $86,255.40$ & 1.06 & 1.03 & $96,881.30$ & 1.10 & 1.09 & $109,147.20$ & 1.03 & 1.16 & $123,410.30$ & 1.05 \\
\hline RS,T,U], & Jass aimnya & 3.30 & $113,022,00$ & 1.23 & 3.10 & $122,5660.20$ & 2.18 & 2.94 & $140,315.50$ & 2.17 & 280 & $163,448,80$ & 1.76 & 2.86 & $190,579,50$ & 1.68 \\
\hline & PDRB dan PDB & 100.01 & $6,251,085.90$ & & 100.02 & $8,429,699,50$ & & 90.01 & $9,308,367,60$ & & 100.00 & $10,302,344,40$ & & 99.99 & $11,178,338,00$ & \\
\hline
\end{tabular}

Sumber: data sekunder diolah penulis, 2017 
Dari hasil perhitungan analisis LQ pada Tabel 2 pada tahun 2011-2015, didapatkan bahwa hanya terdapat satu sektor basis yakni sektor pengadaan listrik dan gas, sedangkan sisanya adalah sektor non basis. Sektor pengadaan listrik dan gas di Kota Bogor memiliki nilai LQ yang jauh lebih tinggi dari pada sektor-sektor lainnya. Hal ini menunjukkan bahwa sektor pengadaan listrik dan gas ini memiliki potensi yang bagus untuk dikembangkan. Dengan bertambah banyaknya kegiatan ekonomi dari sektor pertanian ini akan ikut berpengaruh terhadap kegiatan ekonomi sektor-sektor lain.

Tingginya nilai LQ pada sektor pengadaan listrik dan gas tidak lepas dari peranan dari dua sub sektor utama dari sektor pengadaan listrik dan gas, yang telah memberikan kontribusi yang cukup besar terhadap sektor pengadaan listrik dan gas ini. Dua sub sektor tersebut adalah sub sektor pengadaan listrik dan sub sektor pengadaan gas.

Berdasarkan hasil analisis pada Tabel 2 dapat diketahui kinerja dari masingmasing sektor yakni pada tahun 2011-2015, keseluruhan sektor memiliki nilai pertumbuhan regional (PR) positif. Hal ini menunjukkan semua sektor di Kota Bogor memiliki pertumbuhan yang surplus.

Pada tahun 2011, sektor basis Kota Bogor adalah sektor pengadaaan listrik dan gas, sektor transportasi dan pergudangan, sektor jasa keuangan dan asuransi serta sektor jasa lainnya. Pada tahun 2012-2015, selain keempat sektor pada tahun 2011, sektor pengadaan air, pengelolaan sampah, limbah, sektor konstruksi, serta sektor perdagangan besar dan eceran; reparasi mobil dan sepeda motor juga menjadi sektor basis Kota Bogor. Sektor penyediaan akomodasi, makanan dan minuman, sektor informasi dan komunikasi, sektor jasa perusahaan, sektor jasa kesehatan dan kegiatan sosial. Sehingga, pada tahun 2012-2015, sektor yang menjadi sektor basis Kota Bogor berjumlah sebelas sektor.

\section{SIMPULAN DAN SARAN}

Dari hasil pembahasan yang telah dilakukan pada bab sebelumnya, maka dapat ditarik beberapa simpulan yang akan digunakan untuk menjawab rumusan masalah yang telah diambil oleh peneliti:

Di Kota Bogor dari kurun waktu 2011 hingga 2015 terdapat satu sektor basis tertinggi yakni sektor pengadaan listrik dan gas . Dari 16 sektor ekonomi, sektor ekonomi yang termasuk sektor basis pada 2011adalah pengadaaan listrik dan gas, sektor transportasi dan pergudangan, sektor jasa keuangan dan asuransi serta sektor jasa lainnya. Selain keempat sektor pada tahun 2011, pada tahun 2012-2015, bertambah 7 sektor, menjadi 11. Tambahan sektor itu adalah sektor basis.sektor pengadaan air, pengelolaan sampah, limbah, sektor konstruksi, serta sektor perdagangan besar dan eceran; reparasi mobil dan sepeda motor, sektor penyediaan akomodasi, makanan dan minuman, sektor informasi dan komunikasi, sektor jasa perusahaan, sektor jasa kesehatan dan kegiatan sosial. kemudian yang termasuk dalam sektor non basis adalah lima sektor lainnya.

Di Kota Bogor kinerja sektor perekonomiannya dapat dijelaskan bahwa sektor yang memiliki nilai rata-rata Pertumbuhan Regional (PR) tertinggi yakni sektor pengadaan listrik dan gas . Nilai ini mengindikasikan bahwa pertumbuhan dari sektor pengadaan listrik dan gas di Kota Bogor lebih tinggi dibandingkan dengan Indonesia. Di Kota Bogor dari tahun 2011 hingga 2015 yang termasuk dalam sektor potensial adalah sektor. Kemudian dari 
Resista Vikaliana, Analisis Identifikasi Sektor Perekonomian Sebagai Sektor Basis ...

sektor-sektor tersebut, sektor yang paling potensial atau dapat dikatakan sebagai sektor paling potensial adalah sektor pengadaan listrik dan gas.

Dari hasil penelitian yang telah diperoleh oleh peneliti, maka peneliti memberikan saran yang harus diambil adalah sebagai berikut : Pertama, sektor basis hendaknya harus lebih dijaga dan dikembangkan lagi tanpa menyampingkan pembangunan terhadap sektor-sektor yang lain. Sektor pengadaan listrik dan gas yang memberikan kontribusi terhadap PDRB hendaknya dikembangkan dengan cara melakukan industrialisasi bekerja sama dengan investor, sehingga kontribusi dari sektor pengadaan gas dan listrik dapat kembali meningkat. Kedua, perencanaan dalam pembangunan hendaknya diberikan terhadap sektor-sektor yang memiliki potensi untuk dikembangkan sebagai prioritas utama sehingga pembangunan yang dilakukan nantinya dapat dilaksanakan dengan lebih optimal.

\section{DAFTAR PUSTAKA}

Adisasmita, H. Raharjo. 2005. Dasar-dasar Ekonomi Wilayah. Yogyakarta: Graha Ilmu

Daryanto, Arif dan Yundy Hafizrianda. 2010. Model-model Kuantitatif untuk Perencanaan Pembangunan Ekonomi Daerah. Bogor: IPB Press.

Mudrajad. 2004. Otonomi Dan Pembangunan Daerah: Reformasi,. Perencanaan, Strategi, dan Peluang. Jakarta: Erlangga.

Tarigan, S. 2005. Perencanaan Pembangunan Wilayah. Jakarta: Bumi Aksara

$\underline{\text { Skripsi dan Jurnal }}$ Mushoffa,2009. "Analisis Sektor Basis dan Strategi Pengembangan Potensi Ekonomi Daerah di Kabupaten Tegal”. Skripsi Jurusan Ekonomi
Pembangunan, Fakultas Ekonomi, Universitas Negeri Semarang. Yuuhaa, M. Iqbal Wahyu dan Hendry Cahyono. 2011. Skripsi. Analisis Penentuan Sektor Basis dan Sektor Potensial di Kabupaten Lamongan. Fakultas Ekonomi, Unesa, Kampus Ketintang Surabaya

Sumber Internet:

http://jabarprov.go.id/index.php/news/22282 /2017/04/03/PAD-Kota-Bogor-Tahun2016-Naik-Rp-1585-Miliar http://rilis.id/sektor-wisata-penyumbangterbesar-pad-kota-bogor.html 